\title{
ANALISIS SURVEI KEPUASAN PELANGGAN TERHADAP E-COMMERCE DENGAN METODE SIMPLE ADDITIVE WEIGHTING
}

\section{Eni Pudjiarti ${ }^{1}$, Muhamad Tabrani ${ }^{2}$}

${ }^{1}$ Teknik Informatika, Universitas Nusa Mandiri

Jl. Jatiwaringin No.2, Cipinang Melayu Makasar, Jakarta Timur, e-mail: eni.epr@ nusamandiri.ac.id

${ }^{2}$ Sistem Informasi, Universitas Bina Sarana Informatika Kampus Karawang

Jl. Banten No. 1 Karangpawitan Karawang, e-mail: muhammad.mtb@bsi.ac.id

\section{ARTICLE INFO}

Article history:

Received 10 November 2021

Received in revised form 14 November 2021

Accepted 15 November 2021

Available online 1 Desember 2021

\begin{abstract}
Online shopping is the process of purchasing goods / services by consumers to realtime sellers, without services, and through the internet. The development of online business in Indonesia is now very rapid, one of them by shopping online. Online stores or we often call $e$ commerce is a form of change that is presented by the internet in terms of innovation in shopping by providing various facilities in the transaction process. The aim of the writer is to determine the best e-commerce, therefore the author uses the SAW (Simple Additive Weighting) method because the method is able to make a more precise assessment because it is based on the value of criteria and preference weights that have been determined, besides that the SAW method also can select the best alternative from a number of alternatives because there is a ranking process after determining the weights for each attribute.
\end{abstract}

Keywords: e-commerce, online store, simple additive weighting methods

\begin{abstract}
Abstrak
Belanja online merupakan proses pembelian barang/jasa oleh konsumen ke penjual realtime, tanpa pelayanan, dan melalui internet. Perkembangan bisnis secara online di Indonesia sekarang sangat pesat, salah satunya dengan melakukan belanja secara online. Toko online atau sering kita sebut e-commerce merupakan bentuk perubahan yang disajikan oleh internet dari segi inovasi dalam berbelanja dengan memberikan berbagai kemudahan dalam proses transaksinya. Tujuan penulis adalah untuk menentukan $e$ commerce yang terbaik, maka dari itu penulis menggunakan metode SAW (Simple Additive Weighting) dikarenakan metode tersebut mampu untuk melakukan penilaian secara lebih tepat karena didasarkan pada nilai kriteria dan bobot preferensi yang sudah ditentukan, selain itu metode SAW juga dapat menyeleksi alternatif terbaik dari sejumlah alternatif yang ada kerana adanya proses perangkingan setelah menentukan bobot untuk setiap atribut.
\end{abstract}

Kata Kunci: belanja online, e-commerce, toko online, metode simple additive weighting

\section{PENDAHULUAN}

Received November 10, 2021; Revised November 14, 2021; Accepted November 15, 2021 
p-ISSN: 1907-0012 e-ISSN : 2714-5417

Belanja online (online shop) merupakan proses pembelian barang/jasa oleh konsumen ke penjual realtime, tanpa pelayanan, dan melalui internet. Toko virtual ini mengubah paradigma proses pembeli barang/jasa dibatasi oleh tembok, pengecer, atau mall[1]. Maksudnya, tidak harus bertemu penjual/pembeli secara langsung, tidak perlu menemukan wujud pasar secara fisik, namun hanya dengan menghadap layar monitor / gadget, dengan koneksi internet tersambung, kita dapat melakukan transaksi jual/beli secara cepat dan nyaman.

Perkembangan bisnis secara online di Indonesia sekarang sangat pesat, salah satunya dengan melakukan belanja secara online. Belanja online atau e-commerce merupakan salah satu cara berbelanja melalui alat komunikasi elektronik atau jejaring sosial yang digunakan dalam transaksi jual beli, dimana pembeli tidak perlu susah payah datang ke toko untuk melihat dan membeli apa yang mereka cari, hanya tinggal melihat barang yang diinginkan melalui internet kemudian memesan barang sesuai pilihan dan mentransfer uangnya dan kemudian barang tersebut akan dikirim oleh toko online tersebut kerumah[2].

Toko online atau sering kita sebut e-commerce merupakan bentuk perubahan yang disajikan oleh internet dari segi inovasi dalam berbelanja dengan memberikan berbagai kemudahan dalam proses transaksinya. Gaya hidup masyarakat yang ikut berubah karena pengaruh dari perkembangan teknologi tersebut, salah satu yang paling mencolok adalah gadget dengan kecenderungan beraktivitas di dunia maya seperti berbelanja secara online atau lebih sering disebut dengan belanja online[3].

Penggunaan metode kuantitatif dapat diartikan sebagai metode penelitian yang berlandaskan pada filsafat positivisme, digunakan untuk meneliti pada populasi atau sampel tertentu, teknik pengambilan sampel pada umumnya dilakukan secara random, pengumpulan data menggunakan instrumen penelitian, analisis data bersifat kuantitatif/statistik dengan tujuan untuk menguji hipotesis yang telah ditetapkan[4]. Kekurangan metode kuantitatif adalah karena metode ini berdasarkan pada anggapan-anggapan (asumsi), pengambilan data cenderung berasal dari nilai tertinggi, penelitian tidak subyektif. Sehingga penulis merasa tidak tepat jika metode kuantitatif dipakai dalam penelitian ini.

Penggunaan metode Simple Additive Weighting dikarenakan metode tersebut mampu untuk melakukan penilaian secara lebih tepat karena didasarkan pada nilai kriteria dan bobot preferensi yang sudah ditentukan, selain itu metode Simple Additive Weighting juga dapat menyeleksi alternatif terbaik dari sejumlah alternatif yang ada kerana adanya proses perangkingan setelah menentukan bobot untuk setiap atribut[5].

\section{TINJAUAN PUSTAKA}

\subsection{Metode SAW (Simple Additive Weighting)}

Metode SAW (Simple Additive Weighting) adalah metode penjumlahan terbobot. Konsep dasar metode SAW adalah mencari penjumlahan terbobot dari rating kinerja pada setiap alternative pada semua atribut. Metode SAW membutuhkan proses normalisasi matriks keputusan (x) ke suatu skala yang dapat diperbandingkan dengan semua rating alternative yang ada.

Metode SAW membutuhkan proses normalisasi matriks keputusan (x) ke suatu skala yang dapat diperbandingkan dengan semua rating alternative yang ada, Metode ini merupakan metode yang paling terkenal dan paling banyak digunakan dalam menghadapi situasi Multiple Attribute Decision Making (MADM). MADM itu sendiri merupakan suatu metode yang digunakan untuk mencari alternative optimal dari sejumlah alternative dengan kriteria tertentu.

Metode Simple Additive Weighting sering dikenal dengan istilah metode penjumlahan terbobot[6]. Metode SAW ini mengharuskan pembuat keputusan menentukan bobot bagi setiap atribut. Skor total untuk alternative diperoleh dengan menjumlahkan seluruh hasil perkalian antara rating (yang dapat dibandingkan lintas atribut) dan bobot tiap atribut. Rating tiap atribut haruslah bebas dimensi dalam arti telah melewati proses normalisasi matriks sebelumnya.

\subsection{Langkah-langkah Metode SAW}

1. Menentukan kriteria-kriteria yang akan dijadikan acuan dalam pengambilan keputusan, yaitu $\mathrm{Ci}$.

2. Menentukan rating kecocokan setiap alternative pada setiap kriteria.

3. Membuat matriks keputusan berdasarkan kriteria (Ci), kemudian melakukan normalisasi matriks berdasarkan persamaan yang disesuaikan dengan jenis atribut.

4. Hasil akhir diperoleh dari proses perankingan yaitu penjumlahan dari perkalian matriks ternormalisasi $\mathrm{R}$ dengan vektor bobot sehingga diperoleh nilai terbesar yang dipilih sebagai alternative terbaik (Ai) sebagai solusi.

Formula untuk melakukan normalisasi tersebut adalah :

Rumus pada Atribut benefit : 
$\mathrm{r}_{\mathrm{ij}}=\left\{\frac{x i j}{\operatorname{Max} x i j}\right\}$

Rumus pada Atribut Cost :

$\mathrm{r}_{\mathrm{ij}}=\left\{\frac{\text { Min } x i j}{x i j}\right\}$

Dimana :

$\mathrm{r}_{\mathrm{ij}}=$ rating kinerja ternormalisasi

$\operatorname{Max}_{\mathrm{ij}} \quad=$ nilai maksimum dari setiap baris dan kolom

$\operatorname{Min}_{\mathrm{ij}}=$ nilai minimum dari setiap baris dan kolom

$\mathrm{x}_{\mathrm{ij}}=$ baris dan kolom dari matriks

Dengan $r_{i j}$ adalah rating kinerja ternormalisasi dari alternative Ai pada atribut $\mathrm{Cj} ; \mathrm{I}=1,2, \ldots \mathrm{m}$ dan $\mathrm{j}=$ $1,2, \ldots$.

Nilai preferensi untuk setiap alternative (Vi) diberikan sebagai

$\mathrm{V}_{\mathrm{i}}=\sum_{j=1}^{n} \mathrm{~W}_{\mathrm{j}} \mathrm{r}_{\mathrm{ij}}$

Dimana :

$\mathrm{V}_{\mathrm{i}}=$ Nilai akhir dari alternative

$\mathrm{w}_{\mathrm{j}}=$ Bobot yang telah ditentukan

$\mathrm{r}_{\mathrm{ij}}=$ Normalisasi matriks

Nilai $V_{i}$ yang lebih besar mengindikasikan bahwa alternate Ai lebih terpilih

\subsection{E-Commerce (Electronic Commerce)}

E-Commerce adalah penyebaran, pembelian, penjualan dan pemasaran barang atau jasa melalui sistem elektronik seperti internet atau televisi, www (world wide web), atau jaringan komputer lainnya[7]. ECommerce dapat diartikan seperti arena atau tempat terjadinya transaksi ataupun pertukaran informasi yang terjadi antara penjual dan pembeli pada dunia maya[8].

E-Commerce dapat dilakukan oleh siapa saja dengan mitra bisnisnya, tanpa dibatasi ruang dan waktu. Dalam aktivitas e-commerce sesungguhnya mengandung makna adanya hubungan antara penjual dan pembeli, transaksi antar pelaku bisnis, dan proses internal yang mendukung transaksi dengan perusahaan.

Media yang popular dalam aktivitas e-commerce adalah world wide web (WWW). Oleh karenanya, perbaikan terus menerus mengenai pelayanan yang disediakan oleh sistem web e-commerce akan mempunyai pengaruh yang besar pada tingkat penjualan dan kepuasan konsumen[9]. Adapun stuktur sistem e-commerce berbasis web sebagaimana disajukan pada gambar berikut.

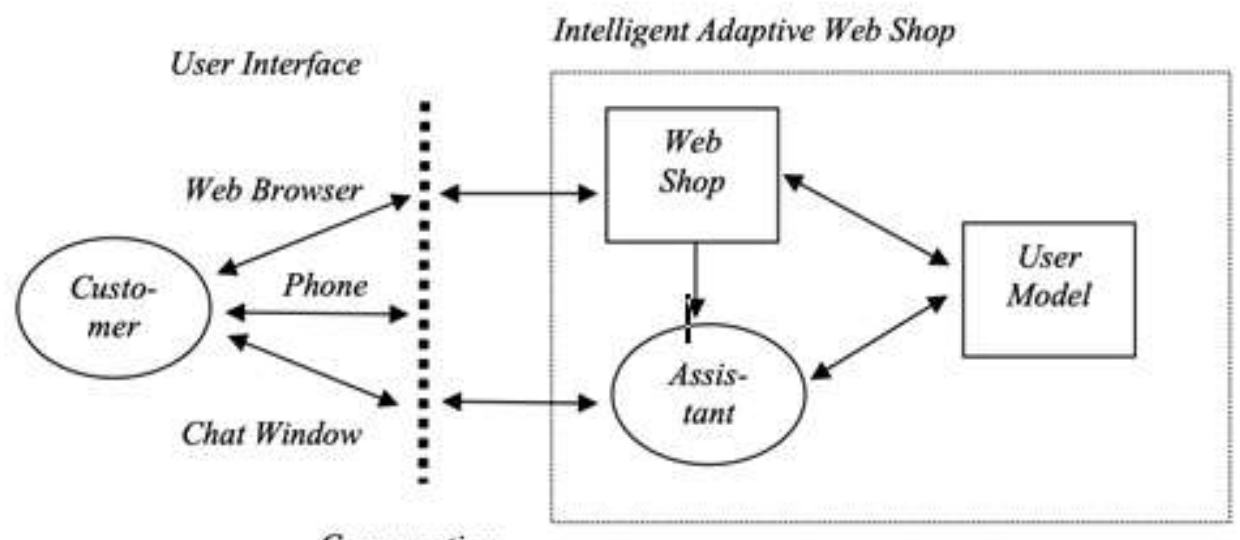

\section{Conversation}

Gambar II. 2 Struktur Sistem E-Commerce

Berdasarkan gambar diatas dapat dijelaskan bahwa konsumen dapat berinteraksi dengan perusahaan penyedia layanan e-commerce melalui tiga jalur (interface), yaitu web browser, telepon atau fasilitas chatting (chat window). Semua informasi mengenai konsumen akan disimpan pada user model dan informasi ini dijadikan oleh perusahaan sebagai database profil konsumen. Informasi profil konsumen tersebut sangat berarti bagi perusahaan dalam kaitannya untuk meningkatkan pelayanan dan kepuasan konsumen.

JURNAL ILMIAH ELEKTRONIKA DAN KOMPUTER, Vol.14, No.2, Desember 2021 
p-ISSN: 1907-0012 e-ISSN : 2714-5417

\section{METODOLOGI PENELITIAN}

Dalam penelitian ini akan menggunakan metode Fuzzy Multiple Atribute Decision Making (FMADM) dengan metode Simple Additive Weighting (SAW) diperlukan kriteria-kriteria dan bobot untuk melakukan perhitungannya sehingga akan didapat alternative terbaik. Simple Additive Weighting (SAW) merupakan metode penjumlahan terbobot. Konsep dasar SAW adalah mencari penjumlahan terbobot dari rating kinerja pada setiap alternatif dan kriteria. Metode SAW membutuhkan proses normalisasi matriks keputusan (x) ke suatu skala yang dapat diperbandingkan dengan semua rating alternatif yang ada.

Metode SAW mengenal adanya 2 (dua) atribut yaitu kriteria keuntungan (benefit) dan kriteria biaya (cost). Perbedaan mendasar dari kriteria-kriteria ini adalah dalam pemilihan kriteria pengambilan keputusan.

Dalam menentukan kepuasan pelanggan terhadap e-commerce yang teliti diperlukan kriteria-kriteria dan bobot untuk melakukan perhitungan sehingga akan didapat alternatif terbaik. Berikut merupakan kriteria yang dibutuhkan untuk pengambilan keputusan, berdasarkan parameter dalam menentukan kepuasan pelanggan terhadap e-commerce.

Tabel III. 1 Kriteria

\begin{tabular}{cc}
\hline Kriteria $\left(\mathbf{C}_{\mathbf{i}}\right)$ & Keterangan \\
\hline $\mathrm{C}_{1}$ & Tampilan \\
\hline $\mathrm{C}_{2}$ & Pilihan Produk / Fitur \\
\hline $\mathrm{C}_{3}$ & Kecepatan Akses \\
\hline $\mathrm{C}_{4}$ & Pelayanan \\
\hline $\mathrm{C}_{5}$ & Promo \\
\hline
\end{tabular}

Dari kriteria tersebut, maka ditentukan suatu tingkatan kepentingan kriteria berdasarkan nilai bobot yang telah ditentukan kedalam bilangan fuzzy. Rating kecocokan setiap alternatif pada setiap kriteria adalah sebagai berikut:

Tabel III. 2 Skala Rating

\begin{tabular}{cc}
\hline Skala Rating & Nilai \\
\hline Sangat Tidak Puas & 1 \\
\hline Tidak Puas & 2 \\
\hline Cukup Puas & 3 \\
\hline Puas & 4 \\
\hline Sangat Puas & 5 \\
\hline
\end{tabular}

Selanjutnya adalah bobot setiap kriteria yang telah di konversikan kedalam bilangan fuzzy, yaitu:

Tabel III. 3 Kriteria Bobot

\begin{tabular}{ccc}
\hline Kriteria $\left(\mathbf{C}_{\mathbf{i}}\right)$ & Keterangan & Bobot \\
\hline $\mathrm{C}_{1}$ & Tampilan & $15 \%$ \\
\hline $\mathrm{C}_{2}$ & Pilihan Produk / Fitur & $25 \%$ \\
\hline $\mathrm{C}_{3}$ & Kecepatan Akses & $20 \%$ \\
\hline $\mathrm{C}_{4}$ & Pelayanan & $15 \%$ \\
\hline $\mathrm{C}_{5}$ & Promo & $25 \%$ \\
\hline
\end{tabular}

\section{HASIL DAN PEMBAHASAN}

Analisa Masalah Menggunakan Metode Simple Additive Weighting

Acuan dalam pembangunan sistem pendukung keputusan (SPK) ini berdasarkan penelitian secara umum dilakukan pada proses pemilihan e-commerce. Dimana dalam penelitian ini setiap e-commerce akan dinilai berdasarkan kreteria. Penelitian ini menggunakan metode Simple Additive Weighting (SAW) diperlukan kriteria-kriteria dan bobot untuk melakukan perhitungan sehingga akan didapat alternative terbaik.

Contoh Kasus : 
Penulis akan menentukan e-commerce yang paling diminati oleh masyarakat dengan menggunakan beberapa kriteria seperti Tampilan, Pilihan Produk / Fitur, Kecepetan Akses, Pelayanan dan Promo dari e-commerce.

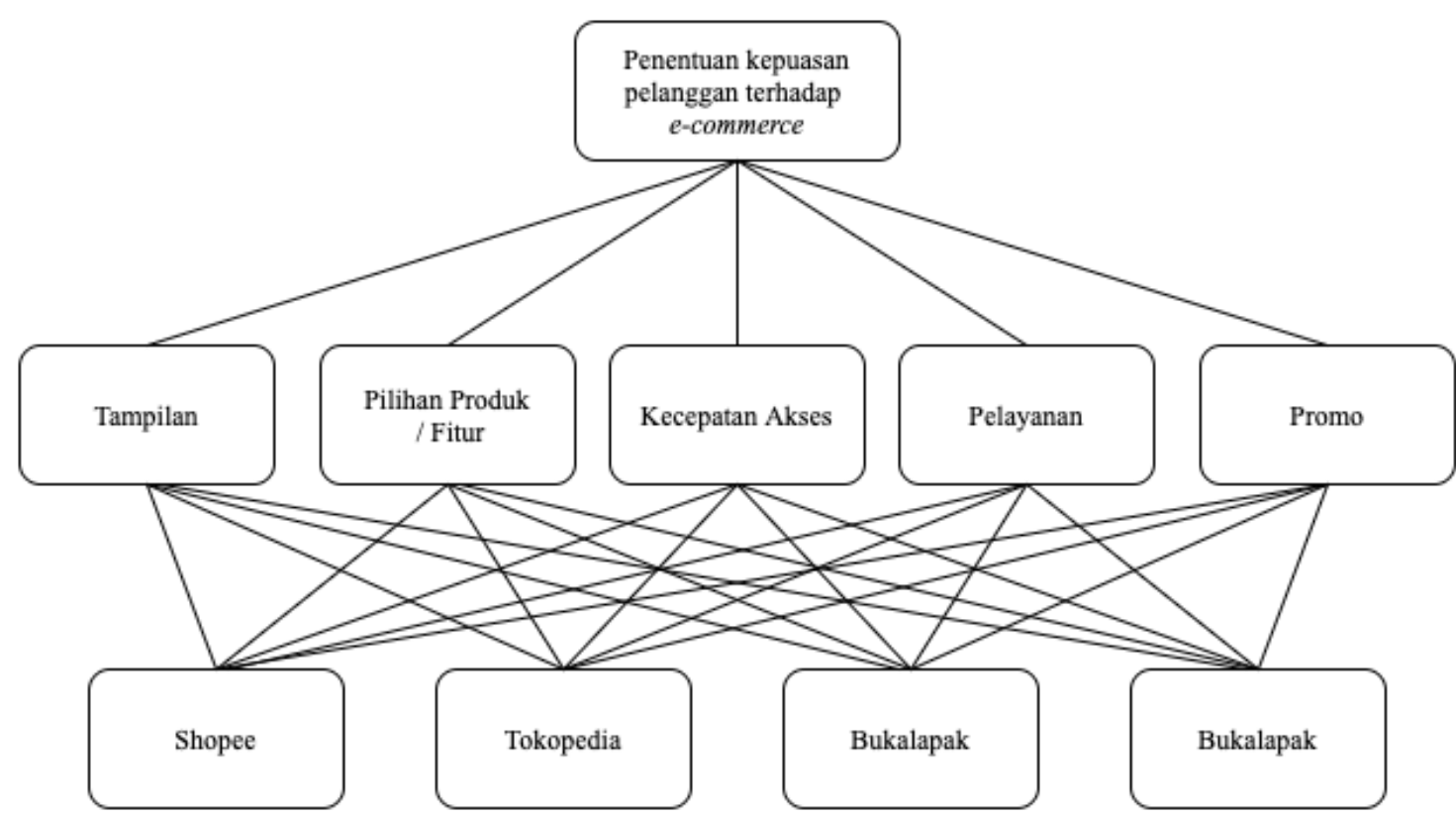

Gambar IV. 1 Hirarki Penentuan E-commere yang paling diminati

Pengolahan Data Menggunakan Metode Simple Additive Weighting

Dalam pengolahan data penelitian, penulis menetapkan langkah-langkah peyelesaian yang sesuai dengan Metode Simple Additive Weighting (SAW) dimana ada empat tahap, yaitu menentukan kriteria yang akan dijadikan acuan, menentukan rating kecocokan setiap alternative pada setiap kriteria, membuat matriks keputusan dan perangkingan[10].

Menentukan kriteria-kriteria yang akan dijadikan acuan dalam pengambilan keputusan, yaitu $\mathrm{Ci}$

Seperti yang penulis sudah jelaskan dalam bab III sebelumnya terdapat 5 variabel yang akan dijadikan kriteria acuan untuk penilaian survei kepuasan pelanggan terhadap e-commerce dengan metode SAW (Simple Additive Weighting) yaitu : tampilan, pilihan produk / fitur, kecepatan akses, pelayanan dan promo.

Dibawah ini adalah tabel daftar nama responden beserta nilai hasil penilaian yang diterima dari google form. Data nilai masing-masing responden tersebut lalu di konversikan ke bilangan fuzzy yang telah ditentukan sebelumnya pada bab III di tabel III.2

Tabel IV. 1 Hasil data responden keseluruhan

\begin{tabular}{llcccccccc}
\hline \multirow{2}{*}{ No } & \multirow{2}{*}{ Nama Responden } & Jenis & \multirow{2}{*}{ Kelamin } & Umur & E-Commerce & \multicolumn{6}{c}{ Kriteria } \\
\cline { 6 - 10 } & & $\mathrm{P}$ & 23 & Shopee & 4 & 4 & 3 & 4 & 3 \\
\hline 1 & Diana Ulfah & $\mathrm{P}$ & 24 & Shopee & 5 & 5 & 4 & 4 & 4 \\
\hline 2 & Riska Fahma & $\mathrm{P}$ & 23 & Shopee & 5 & 4 & 4 & 5 & 3 \\
\hline 3 & Anggun & $\mathrm{L}$ & 23 & Shopee & 5 & 5 & 5 & 5 & 5 \\
\hline 4 & Galang Megandhanu & $\mathrm{P}$ & 23 & Shopee & 4 & 5 & 4 & 5 & 5 \\
\hline 5 & Arin & $\mathrm{P}$ & 22 & Lazada & 4 & 4 & 4 & 4 & 4 \\
\hline 6 & Riske Anggarini & $\mathrm{P}$ & 23 & Shopee & 4 & 3 & 5 & 4 & 4 \\
\hline 7 & Sri Dian Ulan Dari & $\mathrm{L}$ & 23 & Tokopedia & 4 & 4 & 4 & 4 & 3 \\
\hline 8 & Reza & & & & & &
\end{tabular}

JURNAL ILMIAH ELEKTRONIKA DAN KOMPUTER, Vol.14, No.2, Desember 2021 
p-ISSN: 1907-0012 e-ISSN : 2714-5417

\begin{tabular}{|c|c|c|c|c|c|c|c|c|c|}
\hline 9 & Nossita & $\mathrm{P}$ & 29 & Tokopedia & 5 & 5 & 5 & 5 & 5 \\
\hline 10 & Muhammad Dimas P & $\mathrm{L}$ & 22 & Bukalapak & 4 & 3 & 3 & 3 & 3 \\
\hline 11 & Ardan Rangkuti & $\mathrm{L}$ & 23 & Tokopedia & 5 & 5 & 5 & 5 & 5 \\
\hline 12 & Ahmad Deni & $\mathrm{L}$ & 23 & Shopee & 3 & 2 & 3 & 3 & 5 \\
\hline 13 & Alya Maulida & $\mathrm{P}$ & 16 & Shopee & 4 & 4 & 3 & 4 & 3 \\
\hline 14 & Habibah Sifa Mufaroha & $\mathrm{P}$ & 23 & Shopee & 5 & 5 & 5 & 4 & 4 \\
\hline 15 & Dani & $\mathrm{L}$ & 20 & Tokopedia & 5 & 5 & 5 & 5 & 5 \\
\hline 16 & Anita Fitriyanih & $\mathrm{P}$ & 23 & Tokopedia & 4 & 3 & 5 & 4 & 4 \\
\hline 17 & Lutfi Alwi Shihab & $\mathrm{L}$ & 22 & Shopee & 5 & 3 & 4 & 3 & 3 \\
\hline 18 & Nadia Fikriyanti & $\mathrm{P}$ & 24 & Shopee & 4 & 4 & 4 & 4 & 5 \\
\hline 19 & Aca & $\mathrm{P}$ & 22 & Shopee & 4 & 5 & 5 & 4 & 4 \\
\hline 20 & Muhammad Rizki H & $\mathrm{L}$ & 23 & Tokopedia & 5 & 5 & 5 & 5 & 5 \\
\hline 21 & Lina Elita & $\mathrm{P}$ & 22 & Shopee & 4 & 4 & 4 & 3 & 3 \\
\hline 22 & Sindy Setiani & $\mathrm{P}$ & 25 & Shopee & 5 & 5 & 5 & 5 & 5 \\
\hline 23 & Lutfi & $\mathrm{L}$ & 23 & Lazada & 3 & 4 & 3 & 3 & 3 \\
\hline 24 & Sylvyanna Rossa & $\mathrm{P}$ & 21 & Shopee & 3 & 4 & 5 & 3 & 4 \\
\hline 25 & Dyah & $\mathrm{P}$ & 27 & Shopee & 5 & 4 & 4 & 5 & 5 \\
\hline 26 & Syamsul Qomar & $\mathrm{L}$ & 23 & Tokopedia & 4 & 3 & 4 & 4 & 4 \\
\hline 27 & Nur Hidayat & $\mathrm{L}$ & 17 & Shopee & 3 & 5 & 3 & 4 & 3 \\
\hline 28 & Riska Salsabilla & $\mathrm{P}$ & 16 & Lazada & 5 & 4 & 4 & 4 & 5 \\
\hline 29 & Eva Cristianti & $\mathrm{P}$ & 30 & Shopee & 4 & 4 & 4 & 4 & 4 \\
\hline 30 & Muhammad & $\mathrm{L}$ & 22 & Bukalapak & 4 & 4 & 4 & 3 & 3 \\
\hline 31 & Intan & $\mathrm{P}$ & 23 & Shopee & 5 & 5 & 5 & 5 & 5 \\
\hline 32 & Nikken & $\mathrm{P}$ & 27 & Shopee & 5 & 5 & 5 & 5 & 5 \\
\hline 33 & Ahmad Deni & $\mathrm{L}$ & 23 & Shopee & 3 & 2 & 3 & 3 & 5 \\
\hline 34 & Lisnawati & $\mathrm{P}$ & 25 & Shopee & 5 & 5 & 4 & 4 & 4 \\
\hline 35 & Arie & $\mathrm{P}$ & 31 & Shopee & 4 & 3 & 3 & 4 & 5 \\
\hline 36 & Ade Rahmawati & $\mathrm{P}$ & 25 & Lazada & 5 & 5 & 5 & 5 & 5 \\
\hline 37 & Fitria Sinta & $\mathrm{P}$ & 21 & Shopee & 4 & 4 & 4 & 3 & 4 \\
\hline 38 & Muhammad Ihsan & $\mathrm{L}$ & 24 & Shopee & 5 & 5 & 5 & 5 & 5 \\
\hline 39 & Selly Dwi Saputri & $\mathrm{P}$ & 23 & Shopee & 4 & 4 & 3 & 5 & 4 \\
\hline 40 & Vanny Annisa & $\mathrm{P}$ & 24 & Shopee & 5 & 5 & 5 & 5 & 5 \\
\hline 41 & Suci Pebrianti & $\mathrm{P}$ & 19 & Lazada & 5 & 5 & 5 & 5 & 5 \\
\hline 42 & Maudina Rahmah & $\mathrm{P}$ & 24 & Shopee & 5 & 4 & 4 & 4 & 5 \\
\hline 43 & Istiana Safitri & $\mathrm{P}$ & 24 & Shopee & 5 & 5 & 5 & 4 & 5 \\
\hline 44 & Maisya Carlina & $\mathrm{P}$ & 22 & Shopee & 5 & 5 & 5 & 5 & 5 \\
\hline 45 & Rifinovika & $\mathrm{P}$ & 25 & Shopee & 5 & 5 & 5 & 5 & 5 \\
\hline
\end{tabular}


p-ISSN: 1907-0012 e-ISSN : 2714-5417

\begin{tabular}{|c|c|c|c|c|c|c|c|c|c|}
\hline 46 & Istanzah Hujah & $\mathrm{P}$ & 23 & Tokopedia & 5 & 3 & 5 & 5 & 5 \\
\hline 47 & Amaliah Firnanda & $\mathrm{P}$ & 19 & Shopee & 5 & 5 & 5 & 5 & 5 \\
\hline 48 & Farti Elsy Safitri & $\mathrm{P}$ & 23 & Shopee & 5 & 3 & 4 & 4 & 4 \\
\hline 49 & Imamul Arifin & $\mathrm{L}$ & 32 & Lazada & 4 & 4 & 5 & 5 & 5 \\
\hline 50 & Fajar Maulana & $\mathrm{L}$ & 21 & Shopee & 5 & 4 & 4 & 4 & 5 \\
\hline 51 & Elma Yulia & $\mathrm{P}$ & 24 & Shopee & 4 & 4 & 4 & 5 & 4 \\
\hline 52 & Rudi Nursantoso & $\mathrm{L}$ & 21 & Tokopedia & 4 & 2 & 4 & 3 & 4 \\
\hline 53 & Farhan & $\mathrm{L}$ & 24 & Tokopedia & 5 & 5 & 5 & 5 & 5 \\
\hline 54 & Ukhti Fillah & $\mathrm{P}$ & 24 & Shopee & 5 & 3 & 4 & 4 & 4 \\
\hline 55 & Aris Riyadi Prasetyo & $\mathrm{L}$ & 26 & Tokopedia & 3 & 3 & 3 & 4 & 4 \\
\hline 56 & Citra & $\mathrm{P}$ & 19 & Shopee & 5 & 5 & 4 & 5 & 5 \\
\hline 57 & Muhammad Ilhambahri & $\mathrm{L}$ & 22 & Shopee & 5 & 4 & 4 & 5 & 5 \\
\hline 58 & Alvito & $\mathrm{L}$ & 22 & Tokopedia & 5 & 3 & 4 & 5 & 4 \\
\hline 59 & Jorgi Setiawan & $\mathrm{L}$ & 25 & Tokopedia & 4 & 3 & 5 & 4 & 4 \\
\hline 60 & Ahmad Rofiqih & $\mathrm{L}$ & 24 & Shopee & 5 & 5 & 5 & 5 & 5 \\
\hline 61 & Arum & $\mathrm{P}$ & 23 & Shopee & 4 & 5 & 5 & 4 & 5 \\
\hline 62 & Endah & $\mathrm{P}$ & 25 & Shopee & 5 & 4 & 5 & 5 & 5 \\
\hline 63 & Fandi Ahmad & $\mathrm{L}$ & 37 & Bukalapak & 5 & 5 & 4 & 4 & 5 \\
\hline 64 & Sylvyanna Rossa & $\mathrm{P}$ & 21 & Shopee & 3 & 4 & 5 & 3 & 4 \\
\hline 65 & IMAM MUSTAQIM & $\mathrm{L}$ & 29 & Lazada & 5 & 5 & 5 & 5 & 3 \\
\hline 66 & Erna & $\mathrm{P}$ & 24 & Lazada & 5 & 4 & 4 & 5 & 5 \\
\hline 67 & Widia Lestari & $\mathrm{P}$ & 23 & Lazada & 4 & 4 & 4 & 4 & 3 \\
\hline 68 & Debora Nainggolan & $\mathrm{P}$ & 23 & Lazada & 4 & 4 & 4 & 4 & 4 \\
\hline 69 & $\begin{array}{l}\text { jesika marsaulina } \\
\text { simbolon }\end{array}$ & $\mathrm{P}$ & 20 & Lazada & 5 & 5 & 5 & 5 & 5 \\
\hline 70 & olla & $\mathrm{P}$ & 24 & Lazada & 4 & 5 & 4 & 4 & 4 \\
\hline 71 & Ilham $m$ ridwan & $\mathrm{L}$ & 22 & Tokopedia & 5 & 5 & 5 & 5 & 5 \\
\hline 72 & Fandi Ahmad & $\mathrm{L}$ & 37 & Shopee & 4 & 4 & 4 & 4 & 3 \\
\hline 73 & Arvien & $\mathrm{L}$ & 36 & Tokopedia & 4 & 4 & 4 & 4 & 4 \\
\hline 74 & Dimas primadani & $\mathrm{L}$ & 20 & Lazada & 5 & 5 & 5 & 5 & 5 \\
\hline 75 & Eni Pudjiarti & $\mathrm{P}$ & 35 & Tokopedia & 5 & 5 & 5 & 5 & 5 \\
\hline 76 & Fandi Ahmad & $\mathrm{L}$ & 37 & Lazada & 4 & 4 & 3 & 4 & 4 \\
\hline 77 & Fandi Ahmad & $\mathrm{L}$ & 37 & Bukalapak & 4 & 3 & 4 & 4 & 4 \\
\hline 78 & Eni Pudjiarti & $\mathrm{P}$ & 35 & Lazada & 5 & 5 & 5 & 5 & 5 \\
\hline 79 & Zulfikar Indra & $\mathrm{L}$ & 33 & Bukalapak & 4 & 4 & 4 & 4 & 5 \\
\hline 80 & Denzi Junaidi & $\mathrm{L}$ & 34 & Bukalapak & 5 & 4 & 5 & 5 & 5 \\
\hline 81 & Abdul Hakim & $\mathrm{L}$ & 37 & Bukalapak & 4 & 4 & 4 & 4 & 4 \\
\hline
\end{tabular}


p-ISSN: 1907-0012 e-ISSN : 2714-5417

\begin{tabular}{llllllllll}
82 & Isti Fauziah & P & 28 & Bukalapak & 3 & 4 & 4 & 4 & 3 \\
\hline 83 & Rama Putra & L & 22 & Bukalapak & 4 & 4 & 4 & 4 & 4 \\
\hline 84 & Adriansyah B. & L & 21 & Bukalapak & 4 & 5 & 4 & 4 & 3 \\
\hline 85 & Rofi & L & 23 & Bukalapak & 4 & 5 & 5 & 5 & 4 \\
\hline 86 & Primastika & L & 23 & Bukalapak & 5 & 5 & 5 & 4 & 4 \\
\hline 87 & Aditya Yogatama & L & 23 & Bukalapak & 4 & 4 & 3 & 4 & 3 \\
\hline 88 & Piqry & L & 23 & Bukalapak & 5 & 5 & 4 & 4 & 4 \\
\hline
\end{tabular}

Tabel IV. 2 Hasil data responden valid

\begin{tabular}{llcccccccc}
\hline \multirow{2}{*}{ No } & \multirow{2}{*}{ Nama Responden } & \multicolumn{2}{c}{ Jenis } & & \multicolumn{5}{c}{ Kriteria } \\
\cline { 8 - 10 } & Kelamin & & E-Commerce & C1 & C2 & C3 & C4 & C5 \\
\hline 1 & Diana Ulfah & $\mathrm{P}$ & 23 & Shopee & 4 & 4 & 3 & 4 & 3 \\
\hline 2 & Riska Fahma & $\mathrm{P}$ & 24 & Shopee & 5 & 5 & 4 & 4 & 4 \\
\hline 3 & Anggun & $\mathrm{P}$ & 23 & Shopee & 5 & 4 & 4 & 5 & 3 \\
\hline 4 & Galang Megandhanu & $\mathrm{L}$ & 23 & Shopee & 5 & 5 & 5 & 5 & 5 \\
\hline 5 & Arin & $\mathrm{P}$ & 23 & Shopee & 4 & 5 & 4 & 5 & 5 \\
\hline 6 & Riske Anggarini & $\mathrm{P}$ & 22 & Lazada & 4 & 4 & 4 & 4 & 4 \\
\hline 7 & Sri Dian Ulan Dari & $\mathrm{P}$ & 23 & Shopee & 4 & 3 & 5 & 4 & 4 \\
\hline 8 & Reza & $\mathrm{L}$ & 23 & Tokopedia & 4 & 4 & 4 & 4 & 3 \\
\hline 9 & Nossita & $\mathrm{P}$ & 29 & Tokopedia & 5 & 5 & 5 & 5 & 5 \\
\hline 10 & Muhammad Dimas P & $\mathrm{L}$ & 22 & Bukalapak & 4 & 3 & 3 & 3 & 3 \\
\hline 11 & Ardan Rangkuti & $\mathrm{L}$ & 23 & Tokopedia & 5 & 5 & 5 & 5 & 5 \\
\hline 12 & Ahmad Deni & $\mathrm{L}$ & 23 & Shopee & 3 & 2 & 3 & 3 & 5 \\
\hline 13 & Alya Maulida & $\mathrm{P}$ & 16 & Shopee & 4 & 4 & 3 & 4 & 3 \\
\hline 14 & Habibah Sifa Mufaroha & $\mathrm{P}$ & 23 & Shopee & 5 & 5 & 5 & 4 & 4 \\
\hline 15 & Dani & $\mathrm{L}$ & 20 & Tokopedia & 5 & 5 & 5 & 5 & 5 \\
\hline 16 & Anita Fitriyanih & $\mathrm{P}$ & 23 & Tokopedia & 4 & 3 & 5 & 4 & 4 \\
\hline 17 & Lutfi Alwi Shihab & $\mathrm{L}$ & 22 & Shopee & 5 & 3 & 4 & 3 & 3 \\
\hline 18 & Nadia Fikriyanti & $\mathrm{P}$ & 24 & Shopee & 4 & 4 & 4 & 4 & 5 \\
\hline 19 & Aca & $\mathrm{P}$ & 22 & Shopee & 4 & 5 & 5 & 4 & 4 \\
\hline 20 & Muhammad Rizki H & $\mathrm{L}$ & 23 & Tokopedia & 5 & 5 & 5 & 5 & 5 \\
\hline 21 & Lina Elita & $\mathrm{P}$ & 22 & Shopee & 4 & 4 & 4 & 3 & 3 \\
\hline 22 & Sindy Setiani & $\mathrm{P}$ & 25 & Shopee & 5 & 5 & 5 & 5 & 5 \\
\hline 23 & Lutfi & $\mathrm{L}$ & 23 & Lazada & 3 & 4 & 3 & 3 & 3 \\
\hline 24 & Sylvyanna Rossa & $\mathrm{P}$ & 21 & Shopee & 3 & 4 & 5 & 3 & 4 \\
\hline 25 & Dyah & $\mathrm{P}$ & 27 & Shopee & 5 & 4 & 4 & 5 & 5 \\
\hline 26 & Syamsul Qomar & $\mathrm{L}$ & 23 & Tokopedia & 4 & 3 & 4 & 4 & 4 \\
\hline 27 & Nur Hidayat & 16 & Lazada & 5 & 4 & 4 & 4 & 5 \\
\hline 28 & Riska Salsabilla & Shopee & 4 & 4 & 4 & 4 & 4 \\
\hline 29 & Eva Cristianti & & & & & \\
\hline
\end{tabular}


p-ISSN: 1907-0012 e-ISSN : 2714-5417

\begin{tabular}{|c|c|c|c|c|c|c|c|c|c|}
\hline 30 & Muhammad & $\mathrm{L}$ & 22 & Bukalapak & 4 & 4 & 4 & 3 & 3 \\
\hline 31 & Intan & $\mathrm{P}$ & 23 & Shopee & 5 & 5 & 5 & 5 & 5 \\
\hline 32 & Nikken & $\mathrm{P}$ & 27 & Shopee & 5 & 5 & 5 & 5 & 5 \\
\hline 33 & Ahmad Deni & $\mathrm{L}$ & 23 & Shopee & 3 & 2 & 3 & 3 & 5 \\
\hline 34 & Lisnawati & $\mathrm{P}$ & 25 & Shopee & 5 & 5 & 4 & 4 & 4 \\
\hline 35 & Arie & $\mathrm{P}$ & 31 & Shopee & 4 & 3 & 3 & 4 & 5 \\
\hline 36 & Ade Rahmawati & $\mathrm{P}$ & 25 & Lazada & 5 & 5 & 5 & 5 & 5 \\
\hline 37 & Fitria Sinta & $\mathrm{P}$ & 21 & Shopee & 4 & 4 & 4 & 3 & 4 \\
\hline 38 & Muhammad Ihsan & $\mathrm{L}$ & 24 & Shopee & 5 & 5 & 5 & 5 & 5 \\
\hline 39 & Selly Dwi Saputri & $\mathrm{P}$ & 23 & Shopee & 4 & 4 & 3 & 5 & 4 \\
\hline 40 & Vanny Annisa & $\mathrm{P}$ & 24 & Shopee & 5 & 5 & 5 & 5 & 5 \\
\hline 41 & Suci Pebrianti & $\mathrm{P}$ & 19 & Lazada & 5 & 5 & 5 & 5 & 5 \\
\hline 42 & Maudina Rahmah & $\mathrm{P}$ & 24 & Shopee & 5 & 4 & 4 & 4 & 5 \\
\hline 43 & Istiana Safitri & $\mathrm{P}$ & 24 & Shopee & 5 & 5 & 5 & 4 & 5 \\
\hline 44 & Maisya Carlina & $\mathrm{P}$ & 22 & Shopee & 5 & 5 & 5 & 5 & 5 \\
\hline 45 & Rifinovika & $\mathrm{P}$ & 25 & Shopee & 5 & 5 & 5 & 5 & 5 \\
\hline 46 & Istanzah Hujah & $\mathrm{P}$ & 23 & Tokopedia & 5 & 3 & 5 & 5 & 5 \\
\hline 47 & Amaliah Firnanda & $\mathrm{P}$ & 19 & Shopee & 5 & 5 & 5 & 5 & 5 \\
\hline 48 & Farti Elsy Safitri & $\mathrm{P}$ & 23 & Shopee & 5 & 3 & 4 & 4 & 4 \\
\hline 49 & Imamul Arifin & $\mathrm{L}$ & 32 & Lazada & 4 & 4 & 5 & 5 & 5 \\
\hline 50 & Fajar Maulana & $\mathrm{L}$ & 21 & Shopee & 5 & 4 & 4 & 4 & 5 \\
\hline 51 & Elma Yulia & $\mathrm{P}$ & 24 & Shopee & 4 & 4 & 4 & 5 & 4 \\
\hline 52 & Rudi Nursantoso & $\mathrm{L}$ & 21 & Tokopedia & 4 & 2 & 4 & 3 & 4 \\
\hline 53 & Farhan & $\mathrm{L}$ & 24 & Tokopedia & 5 & 5 & 5 & 5 & 5 \\
\hline 54 & Ukhti Fillah & $\mathrm{P}$ & 24 & Shopee & 5 & 3 & 4 & 4 & 4 \\
\hline 55 & Aris Riyadi Prasetyo & $\mathrm{L}$ & 26 & Tokopedia & 3 & 3 & 3 & 4 & 4 \\
\hline 56 & Citra & $\mathrm{P}$ & 19 & Shopee & 5 & 5 & 4 & 5 & 5 \\
\hline 57 & Muhammad Ilhambahri & $\mathrm{L}$ & 22 & Shopee & 5 & 4 & 4 & 5 & 5 \\
\hline 58 & Alvito & $\mathrm{L}$ & 22 & Tokopedia & 5 & 3 & 4 & 5 & 4 \\
\hline 59 & Jorgi Setiawan & $\mathrm{L}$ & 25 & Tokopedia & 4 & 3 & 5 & 4 & 4 \\
\hline 60 & Ahmad Rofiqih & $\mathrm{L}$ & 24 & Shopee & 5 & 5 & 5 & 5 & 5 \\
\hline 61 & Arum & $\mathrm{P}$ & 23 & Shopee & 4 & 5 & 5 & 4 & 5 \\
\hline 62 & Endah & $\mathrm{P}$ & 25 & Shopee & 5 & 4 & 5 & 5 & 5 \\
\hline 63 & Fandi Ahmad & $\mathrm{L}$ & 37 & Bukalapak & 5 & 5 & 4 & 4 & 5 \\
\hline 64 & Sylvyanna Rossa & $\mathrm{P}$ & 21 & Shopee & 3 & 4 & 5 & 3 & 4 \\
\hline 65 & IMAM MUSTAQIM & $\mathrm{L}$ & 29 & Lazada & 5 & 5 & 5 & 5 & 3 \\
\hline 66 & Erna & $\mathrm{P}$ & 24 & Lazada & 5 & 4 & 4 & 5 & 5 \\
\hline 67 & Widia Lestari & $\mathrm{P}$ & 23 & Lazada & 4 & 4 & 4 & 4 & 3 \\
\hline 68 & Debora Nainggolan & $\mathrm{P}$ & 23 & Lazada & 4 & 4 & 4 & 4 & 4 \\
\hline
\end{tabular}

JURNAL ILMIAH ELEKTRONIKA DAN KOMPUTER, Vol.14, No.2, Desember 2021 
p-ISSN: 1907-0012 e-ISSN : 2714-5417

\begin{tabular}{|c|c|c|c|c|c|c|c|c|c|}
\hline 69 & $\begin{array}{l}\text { jesika marsaulina } \\
\text { simbolon }\end{array}$ & $\mathrm{P}$ & 20 & Lazada & 5 & 5 & 5 & 5 & 5 \\
\hline 70 & olla & $\mathrm{P}$ & 24 & Lazada & 4 & 5 & 4 & 4 & 4 \\
\hline 71 & Ilham $m$ ridwan & $\mathrm{L}$ & 22 & Tokopedia & 5 & 5 & 5 & 5 & 5 \\
\hline 72 & Arvien & $\mathrm{L}$ & 36 & Tokopedia & 4 & 4 & 4 & 4 & 4 \\
\hline 73 & Dimas primadani & $\mathrm{L}$ & 20 & Lazada & 5 & 5 & 5 & 5 & 5 \\
\hline 74 & Eni Pudjiarti & $\mathrm{P}$ & 35 & Tokopedia & 5 & 5 & 5 & 5 & 5 \\
\hline 75 & Zulfikar Indra & $\mathrm{L}$ & 33 & Bukalapak & 4 & 4 & 4 & 4 & 5 \\
\hline 76 & Denzi Junaidi & $\mathrm{L}$ & 34 & Bukalapak & 5 & 4 & 5 & 5 & 5 \\
\hline 77 & Abdul Hakim & $\mathrm{L}$ & 37 & Bukalapak & 4 & 4 & 4 & 4 & 4 \\
\hline 78 & Isti Fauziah & $\mathrm{P}$ & 28 & Bukalapak & 3 & 4 & 4 & 4 & 3 \\
\hline 79 & Rama Putra & $\mathrm{L}$ & 22 & Bukalapak & 4 & 4 & 4 & 4 & 4 \\
\hline 80 & Adriansyah B. & $\mathrm{L}$ & 21 & Bukalapak & 4 & 5 & 4 & 4 & 3 \\
\hline 81 & Rofi & $\mathrm{L}$ & 23 & Bukalapak & 4 & 5 & 5 & 5 & 4 \\
\hline 82 & Primastika & $\mathrm{L}$ & 23 & Bukalapak & 5 & 5 & 5 & 4 & 4 \\
\hline 83 & Aditya Yogatama & $\mathrm{L}$ & 23 & Bukalapak & 4 & 4 & 3 & 4 & 3 \\
\hline 84 & Piqry & $\mathrm{L}$ & 23 & Bukalapak & 5 & 5 & 4 & 4 & 4 \\
\hline
\end{tabular}

Tabel IV. 3 Nilai rata-rata

\begin{tabular}{ccccccc}
\hline \multirow{2}{*}{ E-Commerce } & \multirow{2}{*}{$\begin{array}{c}\text { Total } \\
\text { Responden }\end{array}$} & C1 & C2 & C3 & C4 & C5 \\
\cline { 3 - 7 } & 42 & 4,5 & 4,2 & 4,3 & 4,3 & 4,4 \\
\hline Shopee & 16 & 4,5 & 3,9 & 4,6 & 4,5 & 4,4 \\
\hline Tokopedia & 13 & 4,5 & 4,5 & 4,4 & 4,5 & 4,3 \\
\hline Lazada & 13 & 4,2 & 4,3 & 4,1 & 4 & 3,8 \\
\hline Bukalapak & $\mathbf{8 4}$ & & & & & \\
\hline Total & & & & & &
\end{tabular}

Tabel IV. 4 Kriteria Bobot

\begin{tabular}{ccc}
\hline Kriteria $\left(\mathbf{C}_{\mathbf{i}}\right)$ & Keterangan & Bobot \\
\hline $\mathrm{C}_{1}$ & Tampilan & $15 \%$ \\
\hline $\mathrm{C}_{2}$ & Pilihan Produk / Fitur & $25 \%$ \\
\hline $\mathrm{C}_{3}$ & Kecepatan Akses & $20 \%$ \\
\hline $\mathrm{C}_{4}$ & Pelayanan & $15 \%$ \\
\hline $\mathrm{C}_{5}$ & Promo & $25 \%$ \\
\hline
\end{tabular}

1. Menentukan Rating Kecocokan

Langkah selanjutnya adalah menentukan rating kecocokan dari setiap alternatif pada setiap kriteria yang ditunjukan pada tabel dibawah ini :

Tabel IV. 5 Rating Kecocokan

\begin{tabular}{cccccc}
\hline \multirow{2}{*}{ Alternatif } & \multicolumn{5}{c}{ Nilai rata-rata } \\
\cline { 2 - 6 } & C1 & C2 & C3 & C4 & C5 \\
\hline \multirow{2}{*}{ A1 } & 4,57 & 4,42 & 4,28 & 4,28 & 4,14 \\
\hline
\end{tabular}




\begin{tabular}{cccccc} 
A2 & 4,5 & 3,85 & 4,57 & 4,5 & 4,42 \\
\hline A3 & 4,5 & 4,5 & 4,42 & 4,5 & 4,35 \\
\hline A4 & 4,21 & 4,21 & 4 & 4 & 3,85 \\
\hline
\end{tabular}

2. Menentukan Matriks Keputusan

Langkah ketiga pembentukan matriks keputusan (x) yang dibentuk dari tabel rating kecocokan dari setiap alternative pada setiap kriteria sebagai berikut:

$$
X=\left\{\begin{array}{ccccc}
4,5 & 4,2 & 4,3 & 4,3 & 4,4 \\
4,5 & 3,9 & 4,6 & 4,5 & 4,4 \\
4,5 & 4,5 & 4,4 & 4,5 & 4,3 \\
4,2 & 4,3 & 4,1 & 4 & 3,8
\end{array}\right\}
$$

Selanjutnya menghitung nilai normalisasi dari setiap alternative dengan rumus sebagai berikut :

$\mathrm{r}_{\mathrm{ij}}=\left\{\frac{\mathrm{xij} j}{\text { Maxi } x i j}\right\}$ jika $j$ adalah atribut keuntungan (benefit)

$\mathrm{r}_{\mathrm{ij}}=\left\{\frac{\text { Mini } \mathrm{xi} j}{\mathrm{Xij}}\right\}$ jika $j$ adalah atribut biaya (cost)

Keterangan :

1. Simbol $\mathrm{r}_{\mathrm{ij}}$ adalah rating kinerja ternomalisasi

2. Simbol $\mathrm{x}_{\mathrm{ij}}$ adalah nilai

3. Simbol $\mathrm{Max}_{\mathrm{i}}$ adalah nilai terbesar dari setiap kriteria

4. $\mathrm{Simbol}_{\mathrm{Min}}$ adalah nilai terkecil dari setiap kriteria

5. Atribut keuntungan adalah jika nilai terbesar dalam atribut tersebut merupakan nilai terbaik

6. Atribut biaya adalah jika nilai terkecil dalam atribut tersebut merupakan nilai terbaik

a. Kriteria Tampilan $\left(\mathrm{C}_{1}\right)$

$\mathrm{r}_{11}$

$$
=\frac{4,5}{\operatorname{Max}\{4,5 ; 4,5 ; 4,5 ; 4,2\}}=\frac{4,5}{4,5}=1
$$

$\mathrm{r}_{21}$

$$
=\frac{4,5}{\operatorname{Max}\{4,5 ; 4,5 ; 4,5 ; 4,2\}}=\frac{4,5}{4,5}=1
$$

$r_{31}$

$$
=\frac{4,5}{\operatorname{Max}\{4,5 ; 4,5 ; 4,5 ; 4,2\}}=\frac{4,5}{4,5}=1
$$

$\mathrm{r}_{41}$

$$
=\frac{4,21}{\operatorname{Max}\{4,5 ; 4,5 ; 4,5 ; 4,2\}}=\frac{4,2}{4,5}=0,933
$$

b. Kriteria Fitur $\left(\mathrm{C}_{2}\right)$

$$
\begin{aligned}
& \mathrm{r}_{12}=\frac{4,2}{\operatorname{Max}\{4,2 ; 3,9 ; 4,5 ; 4,3\}}=\frac{4,2}{4,5}=0,933 \\
& \mathrm{r}_{22}=\frac{3,9}{\operatorname{Max}\{4,2 ; 3,9 ; 4 ; 5 ; 4 ; 3\}}=\frac{3,9}{4,5}=0,866
\end{aligned}
$$

JURNAL ILMIAH ELEKTRONIKA DAN KOMPUTER, Vol.14, No.2, Desember 2021 
p-ISSN: 1907-0012 e-ISSN : 2714-5417

$r_{32}=\frac{4,5}{\operatorname{Max}\{4,2 ; 3,9 ; 4,5 ; 4,3\}}=\frac{4,5}{4,5}=1$

$r_{42}=\frac{4,3}{\operatorname{Max}\{4,2 ; 3,9 ; 4,5 ; 4,3\}}=\frac{4,3}{4,5}=0,955$

c. Kriteria Kecepatan Akses $\left(\mathrm{C}_{3}\right)$

$$
\begin{array}{ll}
\mathrm{r}_{13} & =\frac{4,3}{\operatorname{Max}\{4 ; 3 ; 4 ; 6 ; 4 ; 4 ; 4 ; 1\}}=\frac{4,3}{4,6}=0,934 \\
\mathrm{r}_{23} & =\frac{4 ; 6}{\operatorname{Max}\{4,3 ; 4 ; 6 ; 4 ; 4 ; 4 ; 1\}}=\frac{4,6}{4,6}=1 \\
& =\frac{4,4}{\operatorname{Max}\{4,3 ; 4 ; 6 ; 4 ; 4 ; 4 ; 1\}}=\frac{4,4}{4 ; 6}=0,956 \\
\mathrm{r}_{33} & =\frac{4,1}{\operatorname{Max}\{4,3 ; 4 ; 6 ; 4 ; 4 ; 4 ; 1\}}=\frac{4,1}{4,6}=0,891
\end{array}
$$

d. Kriteria Pelayanan $\left(\mathrm{C}_{4}\right)$

$$
\begin{aligned}
& \mathrm{r}_{14}=\frac{4,3}{\operatorname{Max}\{4,3 ; 4,5 ; 4,5 ; 4\}}=\frac{4,3}{4,5}=0,955 \\
& \mathrm{r}_{24}=\frac{4,5}{\operatorname{Max}\{4,3 ; 4,5 ; 4,5 ; 4\}}=\frac{4,5}{4,5}=1 \\
& \quad=\frac{4,5}{\operatorname{Max}\{4,3 ; 4,5 ; 4,5 ; 4\}}=\frac{4,5}{4,5}=1 \\
& \mathrm{r}_{34}=\frac{4}{\operatorname{Max}\{4,3 ; 4,5 ; 4,5 ; 4\}}=\frac{4}{4,5}=0,888
\end{aligned}
$$

e. Kriteria Promo $\left(\mathrm{C}_{5}\right)$

$$
\begin{aligned}
& \mathrm{r}_{15}=\frac{4,4}{\operatorname{Max}\{4,4 ; 4,4 ; 4,3 ; 3,8\}}=\frac{4,4}{4,4}=1 \\
& \mathrm{r}_{25}=\frac{4,4}{\operatorname{Max}\{4,4 ; 4 ; 4 ; 4,3 ; 3,8\}}=\frac{4,4}{4,4}=1 \\
& \mathrm{r}_{35}=\frac{4,3}{\operatorname{Max}\{4,4 ; 4,4 ; 4 ; 3 ; 3,8\}}=\frac{4,3}{4,4}=0,977 \\
& \mathrm{r}_{45}=\frac{3,8}{\operatorname{Max}\{4,4 ; 4,4 ; 4,3 ; 3,8\}}=\frac{3,8}{4,4}=0,863
\end{aligned}
$$


Kemudian hasil normalisasi dibuat dalam matriks normalisasi, adapun matriks normalisasi penelitian ini adalah sebagai berikut :

$$
\left\{\begin{array}{ccccc}
1 & 0,933 & 0,934 & 0,955 & 1 \\
1 & 0,866 & 1 & 1 & 1 \\
1 & 1 & 0,956 & 1 & 0,977 \\
0,933 & 0,955 & 0,891 & 0,888 & 0,863
\end{array}\right\}
$$

3. Perangkingan

Langkah terkakhir yaitu, menghitung hasil akhir nilai preferensi $\left(\mathrm{V}_{\mathrm{i}}\right)$ diperoleh dari penjumlahan dari perkalian elemen baris matirks ternormalisasi (R) dengan bobot preferensi (W) adapun bobot yang digunakan adalah sebagai berikut :

$\mathrm{W}=\{0,15 \quad 0,25 \quad 0,20 \quad 0,15 \quad 0,25\}$

Adapun rumus yang digunakan adalah sebagai berikut :

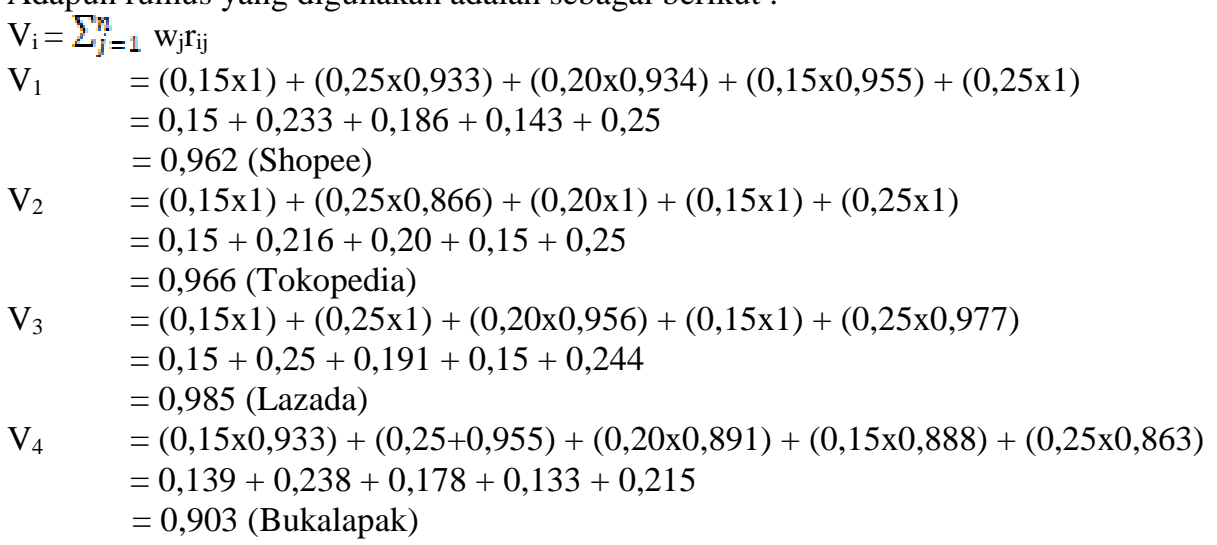

Hasil dari perangkingan diatas dapat disimpulkan hasil dengan perangkingan nilai $\mathrm{V}$, dari nilai terbesar dan terkecil, sehingga didapat alternatif survei kepuasan pelanggan terhadap e-commerce berdasarkan nilai tertinggi terdapat pada tabel berikut ini :

Tabel IV. 6 Hasil Perangkingan

\begin{tabular}{cccc}
\hline No & Alternatif & Hasil Akhir & Rangking \\
\hline 1 & Lazada & 0,985 & 1 \\
\hline 2 & Tokopedia & 0,965 & 2 \\
\hline 3 & Shopee & 0,962 & 3 \\
\hline 4 & Bukalapak & 0,903 & 4 \\
\hline
\end{tabular}

\section{Deskripsi Hasil Analisa Data Penelitian}

Diantara $\mathrm{V}_{1}, \mathrm{~V}_{2}, \mathrm{~V}_{3}$ dan $\mathrm{V}_{4}$ nilai terbesar adalah $\mathrm{V}_{3}$ sehingga alternatif yang terpilih dan berhak menjadi e-commerce dengan kepuasaan pelanggan tertinggi adalah $\mathrm{V}_{3}=$ Lazada dengan hasil $\mathbf{0 , 9 8 7}$ dari perhitungan menggunakan metode Simple Additive Weighting disimpulkan bahwa Lazada merupakan $e$ commerce dengan kepuasan pelanggan tertinggi berdasarkan kriteria-kriteria yang sudah ditentukan sebelumnya. Kemudian kriteria atau layanan yang paling puas adalah C1 (Tampilan) dengan nilai rata-rata yang lebih tinggi dibandingkan dengan kriteria atau layanan yang lainnya.

Tabel IV. 7 Hasil Perangkingan pada Kriteria atau Layanan

\begin{tabular}{lllll}
\hline $\mathrm{C} 1$ & $\mathrm{C} 2$ & $\mathrm{C3}$ & $\mathrm{C4}$ & $\mathrm{C5}$ \\
\hline
\end{tabular}


p-ISSN: 1907-0012 e-ISSN : 2714-5417

\begin{tabular}{lccccc} 
& 4,57 & 4,42 & 4,28 & 4,28 & 4,14 \\
\cline { 2 - 6 } & 4,5 & 3,85 & 4,57 & 4,5 & 4,42 \\
\cline { 2 - 6 } & 4,5 & 4,5 & 4,42 & 4,5 & 4,35 \\
\cline { 2 - 6 } & 4,21 & 4,21 & 4 & 4 & 3,85 \\
\hline Total & $\mathbf{1 7 , 7 8}$ & $\mathbf{1 6 , 9 8}$ & $\mathbf{1 7 , 2 7}$ & $\mathbf{1 7 , 2 8}$ & $\mathbf{1 6 , 7 6}$ \\
\hline Nilai Rata-rata & $\mathbf{4 , 4 4 5}$ & $\mathbf{4 , 2 4 5}$ & $\mathbf{4 , 3 1 7 5}$ & $\mathbf{4 , 3 2}$ & $\mathbf{4 , 1 9}$ \\
\hline
\end{tabular}

\section{KESIMPULAN DAN SARAN}

5.1. Kesimpulan

Berdasarkan hasil penelitian survei kepuasan pelanggan terhadap e-commerce dengan menggunakan metode SAW (Simple Additive Weighting) dapat diambil beberapa kesimpulan. Kesimpulan tersebut dipaparkan sebagai berikut:

1. Dalam kriteria Tampilan (C1) hampir semua mendapat nilai rata-rata yang sama kecuali Bukalapak

2. Dalam kriteria Fitur (C2) responden lebih puas terhadap e-commerce Lazada

3. Dalam kriteria Kecepatan Akses (C3) responden lebih puas terhadap e-commerce Tokopedia

4. Dalam kriteria Pelayanan (C4) responden lebih puas terhadap e-commerce Tokopedia dan Lazada

5. Dalam kriteria Promo (C5) responden lebih puas terhadap e-commerce Shopee dan Tokopedia

6. Sesuai dengan data yang diperoleh peneliti, e-commerce dengan nilai tertinggi terhadap kepuasan pelanggan adalah Lazada dengan nilai $\mathbf{0 , 9 8 5}$

7. E-commerce dengan tingkat kepuasan pelanggan terendah adalah Bukalapak dengan nilai $\mathbf{0 , 9 0 3}$

8. E-commerce yang paling banyak digunakan oleh responden adalah Shopee dengan $\mathbf{4 2}$ responden

9. E-commerce yang paling sedikit digunakan oleh responden adalah Tokopedia dan Bukalapak dengan 13 responden

10. Peringkat survei kepuasan pelanggan terhadap e-commerce dengan metode SAW (Simple Additive Weighting) yang pertama adalah Lazada, kedua Tokopedia, ketiga Shopee dan keempat Bukalapak

\subsection{Saran}

Berdasarkan hasil penelitian ditemukan beberapa permasalahan, sehingga peneliti mengajukan beberapa saran. Saran tersebut antara lain sebagai berikut:

1. Kurangnya jumlah responden dalam pengisian survei kepuasan pelanggan terhadap e-commerce, sebaiknya jumlah responden lebih banyak lagi

2. E-commerce yang digunakan untuk survei kepuasan pelanggan hanya sedikit pilihannya, sebaiknya ditambahkan untuk pilihan e-commerce karena banyak masyarakat yang menggunakan e-commerce lain

3. Sebaiknya untuk pengisian survei kepuasan pelanggan terhadap e-commerce responden diberi hadiah / gift agar banyak yang mengisi survei tersebut

\section{DAFTAR PUSTAKA}

[1] A. K. Setiowati, J. By, and F. E. M. Pasuruan, "Sikap Online Shopping Dan Niat Pencarian Informasi," Manaj. dan Bisnis, vol. 2, no. 1, pp. 1-8, 2012.

[2] L. Nusarika and N. Purnami, "PENGARUH PERSEPSI HARGA, KEPERCAYAAN, DAN ORIENTASI BELANJA TERHADAP NIAT BELI SECARA ONLINE (STUDI PADA PRODUK FASHION ONLINE DI KOTA DENPASAR),” E-Jurnal Manaj. Univ. Udayana, 2015.

[3] A. K. Setiowati, "SIKAP ONLINE SHOPPING DAN NIAT PENCARIAN INFORMASI TERHADAP NIAT DAN PERILAKU BELANJA,” J. Manaj. Bisnis, 2012.

[4] Sugiyono, "Metode Penelitian Pendidikan Pendekatan Kuantitaif, Kualitatif, dan R\&DSugiyono. 2013. 'Metode Penelitian Pendidikan Pendekatan Kuantitaif, Kualitatif, dan R\&D.' Metode Penelitian Pendidikan Pendekatan Kuantitaif, Kualitatif, dan R\&D. https://doi.org/10.1," Metode Penelitian Pendidikan Pendekatan Kuantitaif, Kualitatif, dan R\&D. 2013, doi: 10.1007/s13398014-0173-7.2. 
[5] S. H. Kusumadewi, "Fuzzy Multi-Attribute Decision Making (Fuzzy MADM)," Graha Ilmu Yogyakarta, 2006.

[6] D. Nofriansyah, "Konsep Data Mining Vs Sistem Pendukung Keputusan,” Deepublish, 2014. .

[7] T. Sutabri, Analisa Sistem Informasi. Yogyakarta: Andi, 2012.

[8] R. R. Rerung, E-Commerce. Yogyakarta, 2018.

[9] J. Åberg and N. Shahmehri, "The role of human Web assistants in e-commerce: An analysis and a usability study," Internet Res., 2000, doi: 10.1108/10662240010322902.

[10] S. Nurlela, Akmaludin, S. Hadianti, and L. Yusuf, "Penyeleksian jurusan terfavorit pada smk sirajul falah dengan metode saw," vol. 15, no. 1, pp. 1-6, 2019. 